\title{
Influence of a large dam and importance of an undammed tributary on the reproductive ecology of the threatened fish matrinxã Brycon orthotaenia Günther, 1864 (Characiformes: Bryconidae) in southeastern Brazil
}

\author{
Diego Mendes Ferreira Nunes ${ }^{1}$, André Lincoln Barroso Magalhães ${ }^{1}$, André Alberto \\ Weber $^{1,3}$, Rafael Zeferino Gomes ${ }^{1}$, Felipe Talin Normando ${ }^{1}$, Kleber Biana Santiago ${ }^{2}$, \\ Elizete Rizzo ${ }^{3}$ and Nilo Bazzoli ${ }^{1,3}$
}

\begin{abstract}
A total of 312 adults of matrinxã were captured bimonthly, between 2011-2012, in two sites of the rio São Francisco: immediately downstream of the Três Marias Dam (site 1) and in the confluence with the rio Abaeté (site 2). Specimens of Brycon orthotaenia from site 2 presented higher values of total length $(32.24 \pm 5.70 \mathrm{~cm}$ for females and $26.64 \pm 3.79 \mathrm{~cm}$ for males) and body weight (506.66 $\pm 332.17 \mathrm{~g}$ for females and $267.36 \pm 145.84 \mathrm{~g}$ for males), when compared with the site 1 . In site 2 was registered the highest GSI means $(9.97 \pm 2.96$ for females and $0.93 \pm 0.52$ for males), compared with the site 1 means. Reproduction period occurred from October to February. Unlike site 2, no spawned females or spent males were captured in site 1. Significant differences were found between females and males in site $2\left(\chi^{2}=26.84\right.$, $\left.\mathrm{df}=1, \mathrm{P}<0.05\right)$. Physical-chemical parameters of the water presented higher values in site 2 . The canonical correlation test indicated that the reproduction of males is less susceptible to environmental factors than that of females. These results show that $B$. orthotaenia finds favourable conditions to reproduction just in site 2 .

Um total de 312 adultos de matrinxã foram capturados bimestralmente entre 2011-2012, em dois pontos do rio São Francisco: imediatamente a jusante da barragem de Três Marias (ponto 1) e na confluência com o rio Abaeté (ponto 2). Exemplares de Brycon orthotaenia do ponto 2 apresentaram maiores valores de comprimento total $(32,24 \pm 5,70 \mathrm{~cm}$ para fêmeas e $26,64 \pm$ $3,79 \mathrm{~cm}$ para machos) e peso corporal $(506,66 \pm 332,17 \mathrm{~g}$ para fêmeas e $267,36 \pm 145,84 \mathrm{~g}$ para machos) quando comparado com peixes do ponto 1 . No ponto 2 , foi registrado as maiores médias de IGS $(9,97 \pm 2,96$ para fêmeas e $0,93 \pm 0,52$ para machos) em comparação com o ponto 1 . O período reprodutivo ocorreu de outubro a fevereiro. Ao contrário do ponto 2 , fêmeas desovadas e machos espermiados não foram capturados no ponto 1 . Foram encontradas diferenças significativas entre fêmeas e machos no ponto $2\left(\chi^{2}=26,84, \mathrm{gl}=1, \mathrm{P}<0,05\right)$. Parâmetros físico-químicos da água apresentaram maiores valores no ponto 2. A análise de correlação canônica indicou que a reprodução de machos é menos susceptível a fatores ambientais do que de fêmeas. Estes resultados mostram que B. orthotaenia encontra condições favoráveis para a reprodução apenas no ponto 2.
\end{abstract}

Keywords: Conservation, Gonadosomatic index, Neotropical fish, Migratory fish, Reproduction.

\section{Introduction}

The impacts of dams on aquatic ecosystems have been a topic for discussion, especially relating to fish communities (Antonio et al., 2007; Taylor et al., 2014). Besides altering the natural hydrological regime of rivers, dams directly interfere with species' biological cycle, causing changes in the composition of the ichthyofauna, an increase in vulnerability to predation, behavioural changes and blocking of natural migratory routes (Alvim \& Peret, 2004; Dugan et al., 2010; Freedman et al., 2014). Changes to the environmental conditions downstream from dams negatively affect fish populations and their established reproduction patterns, due to the release of water with different physical and chemical patterns than those of the natural river (Olden \& Naiman, 2010; Reis, 2013).

\footnotetext{
${ }^{1}$ Programa de Pós-graduação em Zoologia de Vertebrados, Pontifícia Universidade Católica de Minas Gerais. Avenida Dom José Gaspar, 500, Coração Eucarístico, 30535-610 Belo Horizonte, MG, Brazil. (DMFN)diegomnunes@hotmail.com, (ALBM) andrebiomagalhaes@ gmail.com, (AAW) aaweber87@gmail.com, (RZG) rafaelzeferino@gmail.com, (FTN) felipetalin@gmail.com, (NB)bazzoli@pucminas. br (corresponding author)

${ }^{2}$ Centro Integrado de Recursos Pesqueiros e Aquicultura de Três Marias, Companhia de Desenvolvimento dos Vales do São Francisco e do Parnaíba, 39205-000 Três Marias, MG, Brazil. kleber.biana@codevasf.gov.br

${ }^{3}$ Departamento de Morfologia, Instituto de Ciências Biológicas, Universidade Federal de Minas Gerais. Avenida Antônio Carlos, 6627, Pampulha, 31270-910 Belo Horizonte, MG, Brazil. ictio@mono.icb.ufmg.br
} 
The Três Marias is a large dam located in southeastern Brazil and was built in 1960 in the upper rio São Francisco for power generation and flood control. In summer occurs a stratification of the reservoir water, with a difference of $3^{\circ} \mathrm{C}$ between the upper and lower layers (Sato et al., 2005). In the power generation process, the colder water from the hypolimnion $\left(3^{\circ} \mathrm{C}\right.$ colder $)$ is released in the river, causing thermal and hydrodynamic changes that impact fish reproduction just downstream of the dam (Weber et al., 2013). Recent studies have shown the importance, for fish reproduction, of tributaries downstream from dams, acting as alternative routes for migratory species and minimising unfavourable water conditions (Antonio et al., 2007; Arantes et al., 2011; Weber et al., 2013; Freitas et al., 2013).

The genus Brycon, previously belonged to subfamily Bryconinae (Lima, 2003) and currently inserted in family Bryconidae (Abe et al., 2014) is widespread over the Neotropical region, and comprises 48 nominal species described for cis-Andean rivers of South America (Carrizo et al., 2013). Species in this genus are among the most threatened in Brazilian rivers and have been since the 1970s (Godoy, 1975). The matrinxã Brycon orthotaenia Günther, 1864 , is a benthopelagic, predominantly herbivorous species endemic to the rio São Francisco basin which migrates during its reproductive period (Alvim \& Peret, 2004; Gonçalves et al., 2006). Its body weight may reach more than $7 \mathrm{~kg}$, thus it is a very important fish for commercial and sport fishing (Gonçalves et al., 2006). In riparian forests in the Neotropics, fruits and seeds is an essential part of the diet of adult Brycon species; and thus these fish play an important role in the dispersal of plants (Azevedo et al., 2011). This migratory species is threatened in rio São Francisco, and it is included in the Red List of the International Union for Conservation of Nature (IUCN), in the category of vulnerable due to an inferred population reduction of greater than $30 \%$ over the last ten years due to overfishing and destruction of riparian vegetation (Reis \& Lima, 2009).

Considering that there are no studies to evaluate the impacts of damming and the importance of tributaries on the Brycon orthotaenia life-history traits, this study aims to analyse the reproductive ecology of this species in two sections of the upper rio São Francisco, immediately downstream from the Três Marias Dam and in the confluence with a free dam tributary in Brazil. We will also suggest conservation strategies to ensure the future survival of this threatened fish.

\section{Material and Methods}

Study area/Field collections. Specimens of Brycon orthotaenia were captured bimonthly, between July 2011 and August 2012 on two sections of upper rio São Francisco: site $1,34 \mathrm{~km}$ of the river immediately downstream from the Três Marias Dam (ca. X-475 324, Y-7989508) and site 2, $54 \mathrm{~km}$ downstream from the dam in the confluence with the rio Abaeté (ca. X-480 595, Y - 8006110) (Fig. 1), Minas
Gerais State, southeastern Brazil. The rio São Francisco has a length of $2,914 \mathrm{~km}$ and it is the longest river that runs entirely in Brazilian territory and the fourth longest in South America (Knoppers et al., 2006). A total of 312 specimens, of which there were 58 females and 50 males from site 1 and 65 females and 139 males from site 2, were captured using gillnets with a mesh size of 4.0 to 7.0 $\mathrm{cm}$. A voucher specimen (MZUSP 95166) was deposited in the Museu de Zoologia da Universidade de São Paulo. The fish, if alive, were killed by transversal section of the cervical medulla, following the ethical principles of animal handling established by the Brazilian College for Animal Experimentation (COBEA, 2014).

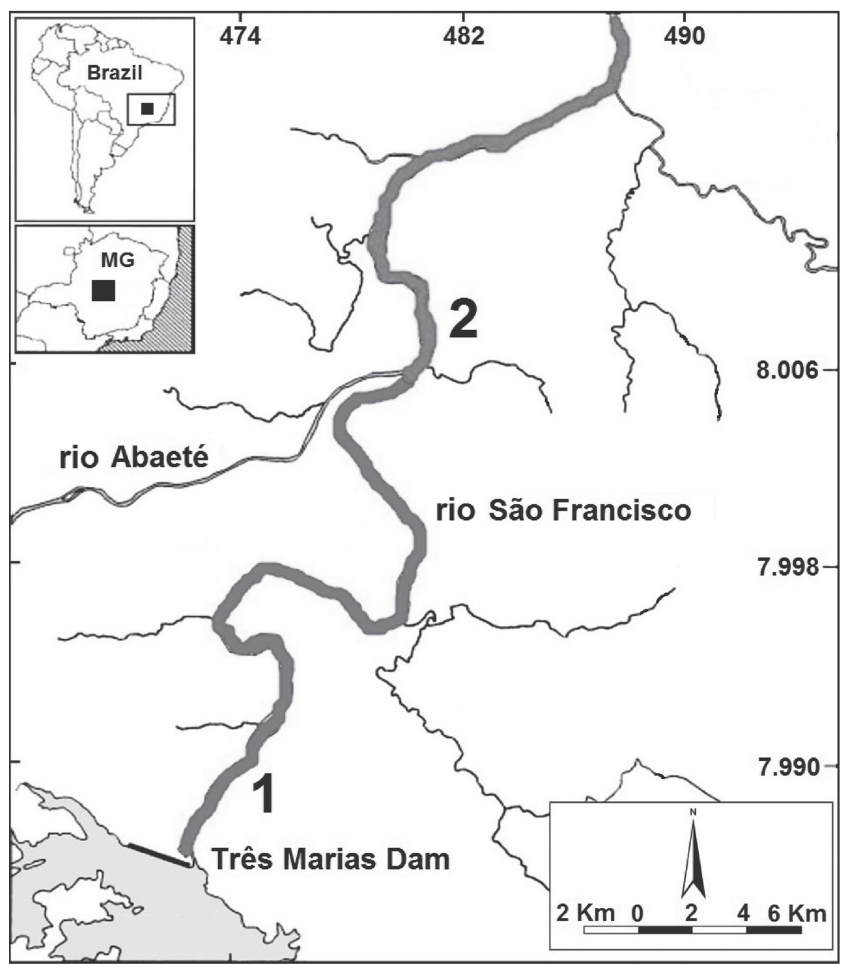

Fig. 1. Location of the study sites of the upper rio São Francisco, downstream from the Três Marias Dam, Minas Gerais State (MG), Brazil. Site 1, immediately downstream from the Três Marias Dam and site 2, below the confluence with the rio Abaeté.

Biological indices, gonadal maturation, follicular diameter, fecundity and sex ratio. For each specimen, total length (TL), body weight (BW) and gonad weight (GW) were recorded. We determined the gonadosomatic index [GSI = $($ gonad weight/(total body weight - gonad weight) $\times 100]$ and Fulton's condition factor $\left(\mathrm{K}=\right.$ body weight/total length ${ }^{3}$ $\times 100$ ). In order to analyse the gonadal development stages, fragments of ovaries and testes were collected and fixed in Bouin's fluid for $24 \mathrm{~h}$, embedded in paraffin, sectioned at a thickness of $4 \mu \mathrm{m}$ and stained with haematoxylin-eosin for histological analyses. The gonadal maturation stages (GMS) were determined based on the microscopic characteristics of the gonads according to Gonçalves et al. (2006). 
The diameters of the vitellogenic follicles were obtained from histological slides of mature ovaries. At least 50 follicles of 10 females captured from each section were measured using an ocular micrometer attached to a light microscope (mean \pm standard deviation). Fragments from mature ovaries of 10 females from site 2, previously weighed and kept in a modified Gilson's solution $(100$ $\mathrm{ml}$ of $60 \%$ ethanol, $880 \mathrm{ml}$ distilled water, $15 \mathrm{ml}$ of $80 \%$ nitric acid, $18 \mathrm{ml}$ of glacial acetic acid and $20 \mathrm{~g}$ of mercury chloride) until the complete dissociation of the oocytes, were observed under a stereoscopic microscope in order to count the vitellogenic follicles and thus determine fecundity. Absolute fecundity (AF) was estimated using the expression: $\mathrm{AF}=\mathrm{OVAGW}$; in which OVA: number of oocytes per ovary gram and $\mathrm{GW}=$ gonadal weight. The relative fecundity was estimated using the following expressions: $\mathrm{RF}=\mathrm{AFTL}^{-1}, \mathrm{RF}=\mathrm{AFBw}^{-1}$, in which $\mathrm{AF}=$ absolute fecundity; $\mathrm{TL}=$ total length; $\mathrm{BW}=$ body weight. The ovaries of females from site 1 did not reach full maturation which is needed for determining fecundity. The sex ratio was calculated from the bimonthly and total number of females and males of $B$. orthotaenia collected in the two sites.

Physical and chemical parameters of the water/ Statistical analyses. Water temperature, dissolved oxygen concentration, $\mathrm{pH}$ and electric conductivity were recorded during the sampling for both sections, using a Horiba model W-10 probe. The water flow rates were supplied by Companhia Energética de Minas Gerais (CEMIG). All studied parameters were submitted to the
Liliefors normality test. For parametric data, we used the T-student test for independent samples and the MannWhitney test for non-parametric data. Chi-square $\left(\chi^{2}\right.$ test) was used to check the differences in proportions between sexes and sites. Canonical correlation between biological parameters such as total length, body weight, gonadosomatic index and environmental factors (water temperature, dissolved oxygen concentration, $\mathrm{pH}$, water flow and electric conductivity) were conduced to females and males of both sections. For comparison between the gonadal maturation stages of females and males, we used the variance Kruskal-Wallis test, followed by the Dunn post-test (Sokal \& Rohlf, 1995). The software used was BioEstat version 5.3 (Ayres et al., 2007) an all tests had a significance level of $\mathrm{P}<0.05$.

\section{Results}

Biological indices, gonadal maturation, follicular diameter and fecundity. Specimens of Brycon orthotaenia captured from site 2 showed statistically higher values of total length and body weight compared to females and males captured from site 1. For both sexes, the average GSI was higher in site 2 in relation to site 1 during the breeding season, showing a statistical difference only for females. The Fulton's condition factor $(\mathrm{K})$ did not show a statistical difference between fishes of the two sites of the river. The vitellogenic follicle diameter (FD) for site 2 showed a slightly higher average than that of site 1 , but with no statistical difference. The fecundity analysis was done only for females of site 2 (Table 1).

Table 1. Biological variables of Brycon orthotaenia females and males captured in two sites of upper rio São Francisco, downstream from the Três Marias Dam. Site 1: Immediately downstream from the Três Marias Dam; Site 2: in the confluence with the rio Abaeté; total length (TL), body weight (BW), gonadosomatic index for mature females (GSI), Fulton condition factor (K), follicular diameter (FD), absolute fecundity (AF), relative fecundity total length (RFTL), relative fecundity body weight (RFBW); data are expressed as mean \pm standard deviation (SD); different superscripts with means in each sex indicate differences between river sections $(\mathrm{P}<0.05)$.

\begin{tabular}{lccccc}
\hline & & \multicolumn{2}{c}{ Site 1} & & Site 2 \\
\cline { 3 - 6 } & & Mean \pm SD & Range & Mean \pm SD & Range \\
\hline \multirow{2}{*}{ TL $(\mathrm{cm})$} & Females & $28.86 \pm 4.17^{\mathrm{a}}$ & $24.00-43.70$ & $32.24 \pm 5.70^{\mathrm{b}}$ & $24.90-49.00$ \\
& Males & $24.45 \pm 2.66^{\mathrm{a}}$ & $20.50-34.20$ & $26.64 \pm 3.79^{\mathrm{b}}$ & $20.60-40.90$ \\
BW $(\mathrm{g})$ & Females & $348.82 \pm 203.73^{\mathrm{a}}$ & $170.00-1134.00$ & $506.66 \pm 332.17^{\mathrm{b}}$ & $191.20-1780.00$ \\
& Males & $202.96 \pm 90.85^{\mathrm{a}}$ & $125.00-582.00$ & $267.36 \pm 145.84^{\mathrm{b}}$ & $121.40-1104.00$ \\
GSI $(\%)$ & Females & $6.15 \pm 2.30^{\mathrm{a}}$ & $2.89-8.30$ & $9.97 \pm 2.96^{\mathrm{b}}$ & $6.90-14.48$ \\
K & Males & $0.91 \pm 0.67^{\mathrm{a}}$ & $0.18-1.95$ & $0.93 \pm 0.52^{\mathrm{a}}$ & $0.17-2.07$ \\
FD $(\mu \mathrm{m})$ & Females & $1.36 \pm 0.17^{\mathrm{a}}$ & $0.84-1.76$ & $1.41 \pm 0.17^{\mathrm{a}}$ & $1.11-2.14$ \\
AF $\left(10^{3}\right)$ & Males & $1.31 \pm 0.19^{\mathrm{a}}$ & $0.96-1.75$ & $1.30 \pm 0.20^{\mathrm{a}}$ & $0.90-2.37$ \\
RFTL $\left(10^{3}\right)$ & Females & $755.41 \pm 54.62^{\mathrm{a}}$ & $631.00-878.30$ & $762.10 \pm 61.91^{\mathrm{a}}$ & $619.50-881.70$ \\
RFBW $\left(10^{2}\right)$ & Females & - & - & $112.02 \pm 67.48$ & $46.58-247.20$ \\
\hline
\end{tabular}


Reproductive activity and sex ratio. Based on microscopic characteristics of the gonads, the following development stages were identified for females $(F)$ and males (M): resting (F1/M1), maturing/mature (F2/M2), spawned (F3) and spent (M3) (Figs. 2-3). More specimens of Brycon orthotaenia in reproductive rest were found in site 1 , whereas the highest quantity of mature fish was recorded for site 2 for both sexes. Spawned females and spent males were only captured in site 2 , after the confluence with the rio Abaeté, and the spawning season occurred in bimesters January/February and March/April (Fig. 4). The short reproductive period and histological characteristics of the spawned ovaries indicate that $B$. orthotaenia presents total spawning. We found no significant differences between females and males of $B$. orthotaenia in the majority of bimesters and for the total period in site $1\left(\chi^{2}=0.60 ; 1.2: 1 ; \mathrm{df}=1 ; \mathrm{P}<0.05\right)$. In site 2 , we found more males than females especially in spawning season $\left(\chi^{2}=7.72 ; 0.4: 1 ; \mathrm{df}=1 ; \mathrm{P}<0.05, \chi^{2}=\right.$
5.08; 0.6:1; $\mathrm{df}=1 ; \mathrm{P}<0.05)$, and overall, males were also more frequent than females $\left(\chi^{2}=26.84 ; 0.5: 1 ; \mathrm{df}=1 ; \mathrm{P}<\right.$ 0.05) (Table 2).

Physical and chemical parameters of the water. Temperature, dissolved oxygen and flow rates were higher downstream from the confluence with the rio Abaeté, site 2, with statistical differences between the sections. Electrical conductivity and $\mathrm{pH}$ showed no statistical difference between sites (Table 3). The canonical correlation between biological parameters and environmental factors showed high correlation and significant difference for females in the two sites of the rio São Francisco (site $1, \mathrm{Rc}=0.66 ; \mathrm{P}<0.0006$ and site $2, \mathrm{Rc}=0.95 ; \mathrm{P}<0.0001)$. However, males of two sections showed low correlation with significant difference between biological parameters and environmental factors only in site 2 (site $1, \mathrm{Rc}=0.41 ; \mathrm{P}=0.1199$ and site $2, \mathrm{Rc}$ $=0.33 ; \mathrm{P}=0.0259$ ).

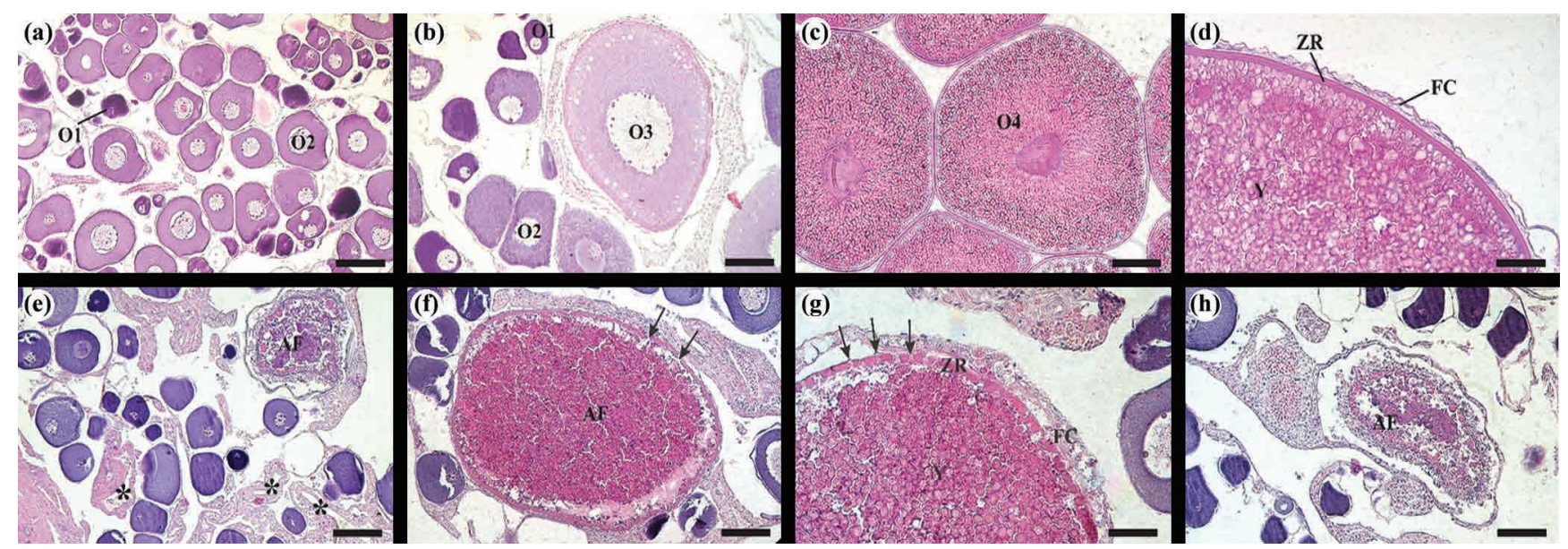

Fig. 2. Histological sections of Brycon orthotaenia ovaries stained with Hematoxilin-eosin: (a) resting stage presenting early $(\mathrm{O} 1)$ and late $(\mathrm{O} 2)$ perinucleolar follicles, (b)(c) maturing/mature stage presenting O1, O2, previtellogenic follicles (O3) and vitellogenic follicles (O4), (d) vitellogenic follicles containing yolk globules (Y), zona radiata (ZR) and follicular cells (FC), (e) spawned stage from site 2 with postovulatory follicles (asterisk) and rare vitellogenic atretic follicles (AF), (f)(g)(h) ovaries of $B$. orthotaenia collected in site 1 possessing several vitellogenic atretic follicles triggered by the cold water released by the Três Marias Dam, (f) vitellogenic follicle in early atresia with fragmented zona radiata (arrows), (g) hypertrophy of follicular cells, fragmented zona radiata (arrows) and yolk being degraded in atretic follicle and (h) vitellogenic follicle in advanced atresia. Bar = (a), (b), (h) $70 \mu \mathrm{m}$, (c) $160 \mu \mathrm{m}$, (d) $40 \mu \mathrm{m}$, (e) $100 \mu \mathrm{m}$, (f) $120 \mu \mathrm{m}$ and (g) $50 \mu \mathrm{m}$.
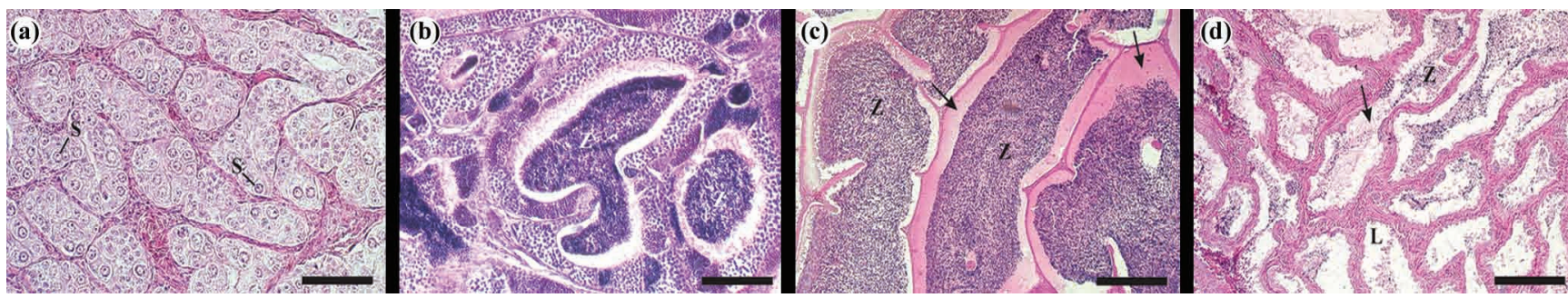

Fig. 3. Histological sections of Brycon orthotaenia testis stained with Hematoxilin-eosin: (a) resting stage with seminiferous tubules cointaining only spermatogonia (S), (b)(c) maturing/mature with seminiferous tubules full of spermatozoa (Z) in acidophilic secretion (arrows) and (d) spent testis with few spermatozoa (Z) in the lumen (L) in acidophilic secretion (arrow). Bar $=$ (a) $30 \mu \mathrm{m}$, (b), (d) $70 \mu \mathrm{m}$, (c) $80 \mu \mathrm{m}$. 
(a)

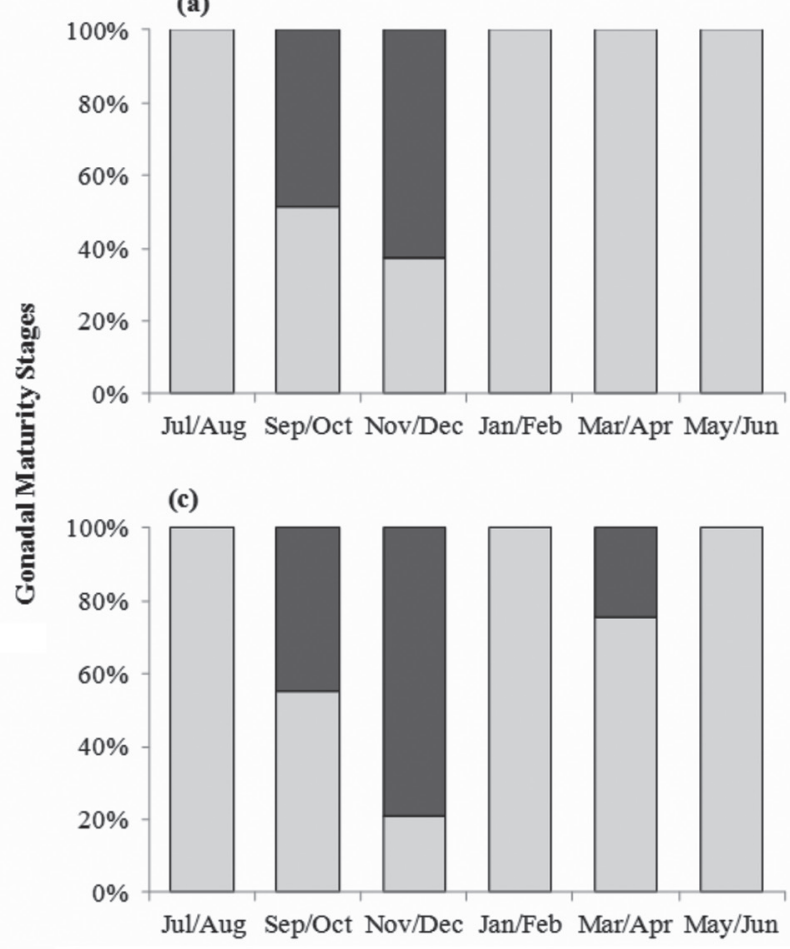

(b)

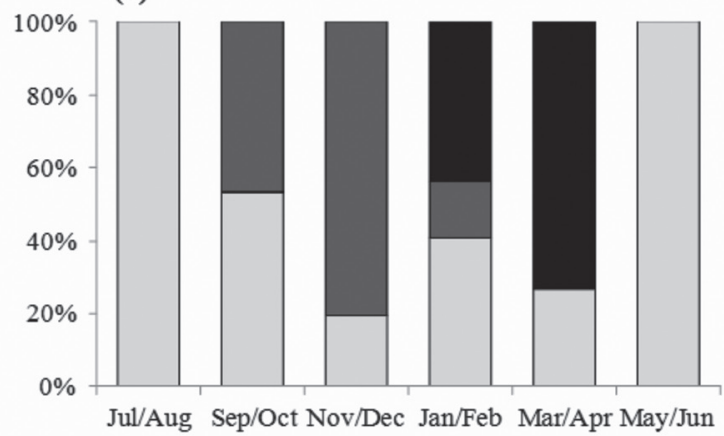

(d)

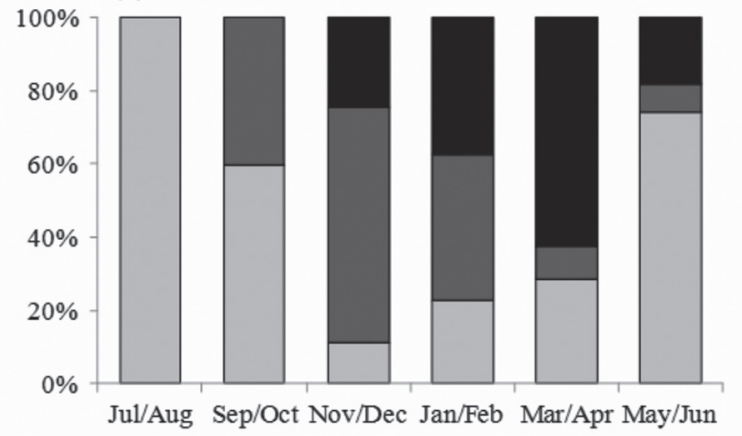

Fig. 4. Relative frequency of maturity stages of Brycon orthotaenia captured in two sites of the rio São Francisco, downstream from the Três Marias Dam. (a) females from site 1, (b) females from site 2, (c) males from site 1 and (d) males from site 2. Resting, light gray; maturing/mature, dark gray; spawning/spent, black.

Table 2. Bimonthly and total sex ratio of Brycon orthotaenia females and males captured in two sites of upper rio São Francisco, downstream from the Três Marias Dam. * Indicates the significant values for sex ratio (Chi-square, $\mathrm{P}<0.05, \chi_{0.05}^{2}$ $=3.84, \mathrm{df}=1)$.

\begin{tabular}{lcccccccc}
\hline \multirow{2}{*}{ Bimesters } & \multicolumn{4}{c}{ Site 1 } & \multicolumn{3}{c}{ Site 2 } \\
\cline { 2 - 8 } & Females & Males & Sex ratio & $\chi^{2}$ & Females & Males & Sex ratio & $\chi^{2}$ \\
\hline July/August & 1 & 1 & $1: 1$ & 0.00 & 2 & 2 & $1: 1$ & 0.00 \\
September/October & 11 & 9 & $1.2: 1$ & 0.2 & 30 & 40 & $0.7: 1$ & 1.42 \\
November/December & 32 & 20 & $1.6: 1$ & 2.76 & 51 & 53 & $1: 1$ & 0.04 \\
January/February & 5 & 1 & $5: 1$ & 2.66 & 12 & 30 & $0.4: 1$ & $7.72^{*}$ \\
March/April & 8 & 12 & $0.7: 1$ & 0.8 & 26 & 45 & $0.6: 1$ & $5.08^{*}$ \\
May/June & 1 & 7 & $0.1: 1$ & $4.5^{*}$ & 2 & 18 & $0.1: 1$ & $12.8^{*}$ \\
Total & 58 & 50 & $1.2: 1$ & 0.60 & 65 & 139 & $0.5: 1$ & $26.84^{*}$ \\
\hline
\end{tabular}

Table 3. Abiotic parameters of the water in two sites of the rio São Francisco, downstream from the Três Marias Dam, between July 2011 and June 2012. Site 1: Immediately downstream from the Três Marias Dam; Site 2: in the confluence with the rio Abaeté. Data are expressed as mean \pm standard deviation (SD); different superscripts with means indicate differences between river sites $(\mathrm{P}<0.05)$.

\begin{tabular}{|c|c|c|c|c|}
\hline & \multicolumn{2}{|c|}{ Site 1} & \multicolumn{2}{|c|}{ Site 2} \\
\hline & Mean \pm SD & Range & Mean \pm SD & Range \\
\hline Temperature $\left({ }^{\circ} \mathrm{C}\right)$ & $23.21 \pm 0.57^{\mathrm{a}}$ & $22.68-24.00$ & $24.31 \pm 0.71^{\mathrm{b}}$ & $23.58-25.40$ \\
\hline Oxygen $(\mathrm{mg} / \mathrm{L})$ & $5.55 \pm 1.67^{\mathrm{a}}$ & $4.13-8.12$ & $7.97 \pm 0.55^{\mathrm{b}}$ & $7.33-8.65$ \\
\hline $\mathrm{pH}$ & $5.83 \pm 0.46^{\mathrm{a}}$ & $5.12-6.24$ & $6.35 \pm 0.51^{\mathrm{a}}$ & $5.62-7.02$ \\
\hline Conductivity $(\mu \mathrm{S} / \mathrm{cm})$ & $68.6 \pm 1.51^{\mathrm{a}}$ & $67.00-71.00$ & $64.2 \pm 7.19^{\mathrm{a}}$ & $56.00-74.00$ \\
\hline Flow $\left(\mathrm{m}^{3} / \mathrm{s}\right)$ & $693.22 \pm 100.58^{\mathrm{a}}$ & $584.93-798.22$ & $815.13 \pm 52.71^{\mathrm{b}}$ & -854.51 \\
\hline
\end{tabular}




\section{Discussion}

This study showed differences in the life traits of Brycon orthotaenia in two sites of the upper rio São Francisco. Total length, body weight and GSI values for females and males and FD for females captured in site 2 were higher than those of site 1 . This is due to presence of riparian vegetation (Alvim \& Peret, 2004) that allows conditions for somatic growth through feeding and warm water temperature and high dissolved oxygen (Weber et al., 2013), which assist in gonadal maturation, as this is one of the most preserved sections of the rio São Francisco (Alvim \& Peret, 2004). Moreover, higher temperatures and higher dissolved oxygen rates are contributory factors for the production of oocytes that are larger in diameter and quantity in long-distance migratory fish species (Weber et al., 2013).

Fecundity estimates are essential for determining the reproductive potential of fish species, and their values are important for understanding the biological status and the reproductive potential of a population (Kennedy et al., 2009). When compared to some other Neotropical teleosts, like those with non-migratory strategy, $B$. orthotaenia showed a high fecundity, a common characteristic for migratory fish that exhibit total spawning (Arantes et al., 2011; Freitas et al., 2013).

The results of this study showed that $B$. orthotaenia presents reproductive success only in site 2 after the confluence with the rio Abaeté from January to April, and in site 1 the reproduction of these species is not successful. This is due to colder water temperature for reproduction in site 1 (Arantes et al., 2011), since, immediately downstream from dams, the release of cold water is responsible for impaired fish reproductive activity (Olden \& Naiman, 2010, Normando et al., 2014). Although the sex ratio of Neotropical fishes is usually 1:1 (Lowe-McConnell, 1987), the female to male ratio found for the matrinxã in site 2 was male biased-sex ratio. According to Wootton (1998), some fish species with external fertilization had a higher male ratio during the reproductive cycle (e.g., mass or group spawning: each female reproduces with many males). However, most females have high levels of fecundity, which is advantageous since males are able to fertilize a larger number of oocytes, thus increasing the odds of perpetuation of the species.

Identifying life strategy is important for the conservation of natural stocks of fish (Lowe-McConnel, 1987). Migratory species typically have a reproductive strategy of periodic type, with high fecundity rates which are dependent of favourable environmental conditions for triggering the reproductive process (Winemiller \& Rose, 1992). In the present study, B. orthotaenia presented a periodic strategy, with high fecundity and total spawning, occurring during the period of high water temperature, dissolved oxygen concentration, and flow in site 2 . The canonical correlation shows that reproduction in males of matrinxã is less susceptible to environmental factors than that of females especially in site 1 due to the colder water from the hypolimnion released by the Três Marias Dam, as has also been reported for other important Neotropical migratory characiforms from the rio São Francisco such as curimatã-pacu Prochilodus argenteus (Sato et al., 2005; Arantes et al., 2011), piau-três-pintas Leporinus reinhardti (Weber et al., 2013) and dourado Salminus franciscanus (Freitas et al., 2013). Recently, a similar tendency also was observed in a small-sized non-migratory characid named lambari-do-rabo-vermelho Astyanax fasciatus downstream from the Três Marias Dam (Normando et al., 2014).

Our findings suggest the need for taking in situ and ex situ conservation strategies to minimise the impacts imposed by the dam. Firstly, preservation of undammed tributaries that ensures spawning success and the maintenance of migratory species. According to Sato et al. (2005) and Freitas et al. (2013), the rio Abaeté is important free dam mid-sized tributary for the migration and spawning of long-distance migratory fishes in upper rio São Francisco. Secondly, maintenance of riparian vegetation in site 2 and in the rio Abaeté because B. orthotaenia depends these areas for feeding. Due to their dependence on plant material in their diet (e.g., leaves, flowers, seeds, fruits), the destruction of riparian vegetation in site 2 could have serious consequences for this fish like extinction (Alvim $\&$ Peret, 2004). In a geographical area, some species are the first to disappear as result of anthropic pressures, and among Neotropical fish, this is particularly true of the genus Brycon (Gomiero et al., 2008). This disappearance can be attributed to the loss of riverine forests (Reys et al., 2009). Thirdly, include the site 2 of the Rio São Francisco as a priority area for conservation of $B$. orthotaenia and other migratory species. According to Drummond et al. (2005), the site 2 is not a priority area for native fish conservation in Minas Gerais State and Brazil, however, the use this site as feeding (Alvim \& Peret, 2004) and spawning grounds for migratory fishes such as $P$. argenteus (Sato et al., 2005; Arantes et al., 2011), L. reinhardti (Weber et al., 2013), S. franciscanus (Freitas et al., 2013), and B. orthotaenia (this study), shows that the site 2 is important area for survival of these species. Fourthly, restocking using $B$. orthotaenia juveniles dowstream of Três Marias Dam is indicated. A successful conservation program based on restocking using matrinxã juveniles from a governmental hatchery, the Companhia de Desenvolvimento dos Vales do São Francisco e do Parnaíba (CODEVASF) has been conducted in the area of dam. Brycon orthotaenia, which was practically extinct above Três Marias Dam, has been tenuously reestablished after reintroductions began in 1988 (Sato \& Godinho, 2003). Lastly, the ex situ strategy suggested for the conservation of matrinxã is the cryopreservation of semen. A practical and inexpensive protocol to freeze B. orthotaenia spermatozoa was developed by Melo \& Godinho (2006) to be used in artificial breeding programs aimed at preserving this species. 
Finally, in Brazil, most large rivers have been modified at some extent by large hydroelectric dams (Agostinho et al., 2007; Araújo et al., 2013). When a river becomes impounded, the migratory species acclimatize to the new sites (i.e., tributaries); if they fail to do so, they will be eliminated (Antonio et al., 2007; Silva et al., 2015). Our results represent an alert, and this statement applies for the threatened B. orthotaenia of upper rio São Francisco.

\section{Acknowledgments}

The authors thank the partnership of Companhia Energética de Minas Gerais (CEMIG-GT)/Companhia de Desenvolvimento dos Vales do São Francisco e do Parnaíba (CODEVASF) and the Brazilian research foundations of Conselho Nacional de Desenvolvimento Científico e Tecnológico (CNPq), Coordenação de Aperfeiçoamento de Pessoal de Nível Superior (CAPES) and Fundação de Amparo a Pesquisa do Estado de Minas Gerais (FAPEMIG) for financial support.

\section{References}

Abe, K. T., T. C. Mariguela, G. S. Avelino, F. Foresti \& C. Oliveira. 2014. Systematic and historical biogeography of the Bryconidae (Ostariophysi: Characiformes) suggesting a new rearrangement of its genera and an old origin of Mesoamerican ichthyofauna. BMC Evolutionary Biology, 14: 1-15.

Agostinho, C. S., A. A. Agostinho, F. M. Pelicice, D. A. A. Almeida \& E. E. Marques. 2007. Selectivity of fish ladders: a bottleneck in Neotropical fish movement. Neotropical Ichthyology, 5: 205-213.

Alvim, M. C. C. \& A. C. Peret. 2004. Food resources sustaining the fish fauna in a section of the Upper São Francisco River in Três Marias, MG, Brazil. Brazilian Journal of Biology, 64: 195-202.

Antonio, R. R., A. A. Agostinho, F. M. Pelicice, D. Bailly, E. K. Okada \& J. H. P. Dias. 2007. Blockage of migration routes by dam construction: can migratory fish find alternative routes? Neotropical Ichthyology, 5: 177-184.

Arantes, F. P., H. B. Santos, E. Rizzo, Y. Sato \& N. Bazzoli. 2011. Collapse of the reproductive process of two migratory fish (Prochilodus argenteus and Prochilodus costatus) in the Três Marias Reservoir, São Francisco River, Brazil. Journal of Applied Ichthyology, 27: 847-853.

Araújo, E. S., E. E. Marques, I. S. Freitas, A. L. Neuberger, R. Fernandes \& F. M. Pelicice. 2013. Changes in distance decay relationships after river regulation: similarity among fish assemblages in a large Amazonian River. Ecology of Freshwater Fish, 22: 543-552.

Azevedo, P. G., R. M. C. Melo \& R. J. Young. 2011. Feeding and social behavior of the piabanha, Brycon devillei (Castelnau, 1855) (Characidae: Bryconinae) in the wild, with a note on following behavior. Neotropical Ichthyology, 9: 807-814.

Ayres, M., M. Ayres Jr., D. L. Ayres \& A. S. Santos. 2007. BioEstat 5.0: aplicações estatísticas nas áreas das Ciências Bio-médicas. Belém, Sociedade Civil Mamirauá; Brasília, CNPq, 364p.
Carrizo, S. F., K. G. Smith \& W. R. T. Darwall. 2013. Progress towards a global assessment of the status of freshwater fishes (Pisces) for the IUCN Red List: application to conservation programmes in zoos and aquariums. International Zoo Yearbook, 47: 46-64.

COBEA. 2014. Sociedade Brasileira de Ciência em Animais de Laboratório. Available from: http://www.cobea.org.br (20 April 2014).

Drummond, G. M., C. S. Martins, A. B. M. Machado, F. A. Sebaio \& Y. Antonini. 2005. Biodiversidade em Minas Gerais: um atlas para sua conservação. 2. ed. Belo Horizonte, Fundação Biodiversitas, 222p.

Dugan, P. J., C. Barlow, A. A. Agostinho, E. Baran, G. F. Cada, D. Chen, I. G. Cowx, J. W. Ferguson, T. Jutagate, M. MallenCooper, G. Marmulla, J. Nestler, M. Petrere, R. L. Welcomme \& K. O. Winemiller. 2010. Fish migration, dams, and loss of ecosystem services in the Mekong basin. Ambio, 39: 344348.

Freedman, J. A., B. D. Lorson, R. B. Taylor, R. F. Carline \& J. R. Stauffer Jr. 2014. River of the dammed: longitudinal changes in fish assemblages in response to dams. Hydrobiologia, 727: 19-33.

Freitas, L. J. A., P. S. Prado, F. P. Arantes, K. B. Santiago, Y. Sato, N. Bazzoli \& Rizzo, E. 2013. Reproductive biology of the characid dourado Salminus franciscanus from the São Francisco River, Brasil. Animal Reproduction Science, 139: 145-154.

Godoy, M. P. 1975. Peixes do Brasil: subordem Characoidei, bacia do rio Mogi Guassu. São Paulo, Franciscana, 846p. 4v.

Gomiero, L. M., A. G. Manzatto \& F. M. S. Braga. 2008. The role of riverine forests for food supply for the omnivorous fish Brycon opalinus Cuvier, 1819 (Characidae) in the Serra do Mar, Southeast Brazil. Brazilian Journal of Biology, 68: 321-328.

Gonçalves, T. L., N. Bazzoli \& M. F. G. Brito. 2006. Gametogenesis and reproduction of the matrinxã Brycon orthotaenia (Günther, 1864) (Pisces: Characidae) in the São Francisco River, Minas Gerais, Brazil. Brazilian Journal of Biology, 66: 513-522.

Kennedy, J., A. C. Gundersen \& J. Boje. 2009. When to count your eggs: is fecundity in Greenland halibut (Reinhardtius hippoglossoides W.) down-regulated? Fisheries Research, 100: 260-265.

Knoppers, B., P. R. P. Medeiros, W. F. L. de Souza \& T. Jennerjahn. 2006. The São Francisco Estuary, Brazil. Pp. 51-70. In: Wangersky, P. J. (Ed.). Estuaries. Berlin Springer-Verlag, 2006 (The handbook of environmental chemistry, v. 5H).

Lima, F. C. T. 2003. Subfamily Bryconinae (Characins, tetras). Pp. 174-181. In: Reis R. E., S. O. Kullander \& C. J. Ferraris, Jr. (Orgs.). Check list of the freshwater fishes of South and Central America. Porto Alegre, Edipucrs.

Lowe-McConnell, R. H. 1987. Ecological studies in tropical fish communities. London, Cambridge University Press, 382p. (Cambridge tropical biology series).

Melo, F. C. S. A. \& H. P. Godinho. 2006. A protocol for cryopreservation of spermatozoa of the fish Brycon orthotaenia. Animal Reproduction, 3: 380-385.

Normando, F. T., K. B. Santiago, M. V. T. Gomes, E. Rizzo \& N. Bazzoli. 2014. Impact of the Três Marias dam on the reproduction of the forage fish Astyanax bimaculatus and $A$. fasciatus from the São Francisco River, downstream from the dam, southeastern Brazil. Environmental Biology of Fishes, 97: 309-319. 
Olden, J. D. \& R. J. Naiman. 2010. Incorporating thermal regimes into environmental flows assessments: modifying dam operations to restore freshwater ecosystem integrity. Freshwater Biology, 55: 86-107.

Reis, R. E. 2013. Conserving the freshwater fishes of South America. International Zoo Yearbook, 47: 65-70.

Reys, P., J. Sabino \& M. Galetti. 2009. Frugivory by the fish Brycon hilarii (Characidae) in western Brazil. Acta Oecologica, 35: 136-141.

Sato, Y., N. Bazzoli, E. Rizzo, M. B. Boschi \& M. O. T. Miranda. 2005. Influence of Abaeté River on the reproduction success of the neotropical migratory teleost Prochilodus argenteus in the São Francisco River, downstream of the Três Marias dam, Southeastern Brazil. River Research and Applications, 21: 939-950.

Sato, Y. \& H. P. Godinho. 2003. Migratory fishes of the São Francisco River. Pp. 195-232. In: Carolsfeld, J., B. Harvey, C. Ross \& A. Baer (Eds.). Migratory fishes of South America: biology, fisheries and conservation status. Ottawa, World Fisheries Trust/The World Bank/International Development Research Centre.

Silva, P. S., M. C. Makrakis, L. E. Miranda, S. Makrakis, L. Assumpção, S. Paula, J. H. P. Dias \& H. Marques. 2015. Importance of reservoir tributaries to spawning of migratory fish in the upper Paraná River. River Research and Applications, 31: 313-322.
Sokal, R. R. \& F. J. Rohlf. 1995. Biometry: the principles and practice of statistics in biological research. New York, W. H. Freeman, 887p.

Taylor, J. M, T. S. Seilheimer \& W. L. Fisher. 2014. Downstream fish assemblage response to river impoundment varies with degree of hydrologic alteration. Hydrobiologia, 728: 23-39.

Weber, A. A., D. M. F. Nunes, R. Z. Gomes, E. Rizzo, K. B. Santiago \& N. Bazzoli. 2013. Downstream impacts of a dam and influence of a tributary on the reproductive success of Leporinus reinhardti in São Francisco River. Aquatic Biology, 19: 195-200.

Winemiller, K. O. \& K. A. Rose. 1992. Patterns of life-history diversification in North American fishes: implications for population regulation. Canadian Journal of Fisheries and Aquatic Science, 49: 2196-2218.

Wootton, R. J. 1998. Ecology of teleost fishes. Dordrecht, 2nd ed., Kluwer Academic, 386p.
Submitted June 5, 2014

Accepted February 10, 2015 by Paulo Pompeu

Published June 30, 2015 